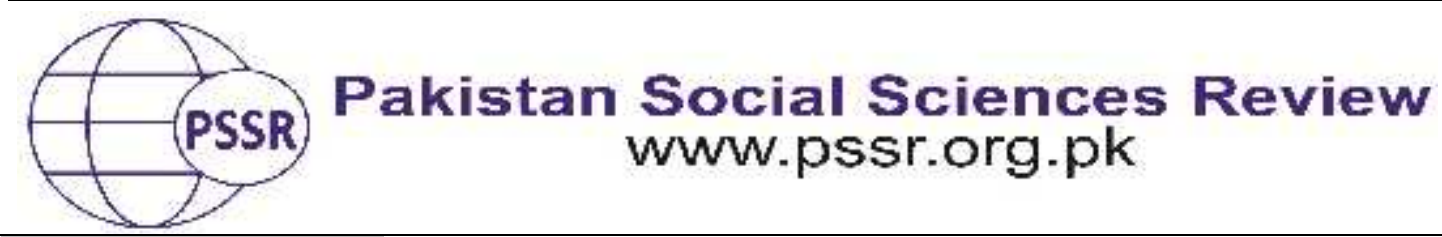

RESEARCH PAPER

\title{
A Critical Reflection on the Complex Nexus of Ideology, Power and Curricula in Pakistani Schools
}

\author{
Dr. Asma Aftab* ${ }^{*}$ Uzma Naqvi $^{2}$ Syeda Hibba Zainab Zaidi ${ }^{3}$
}

1. Assistant Professor, Department of English, Government College University, Faisalabad, Punjab, Pakistan

2. Visiting Faculty, Department of English, Government College University, Faisalabad, Punjab, Pakistan

3. Visiting Faculty, Department of English, Government College University, Faisalabad, Punjab, Pakistan

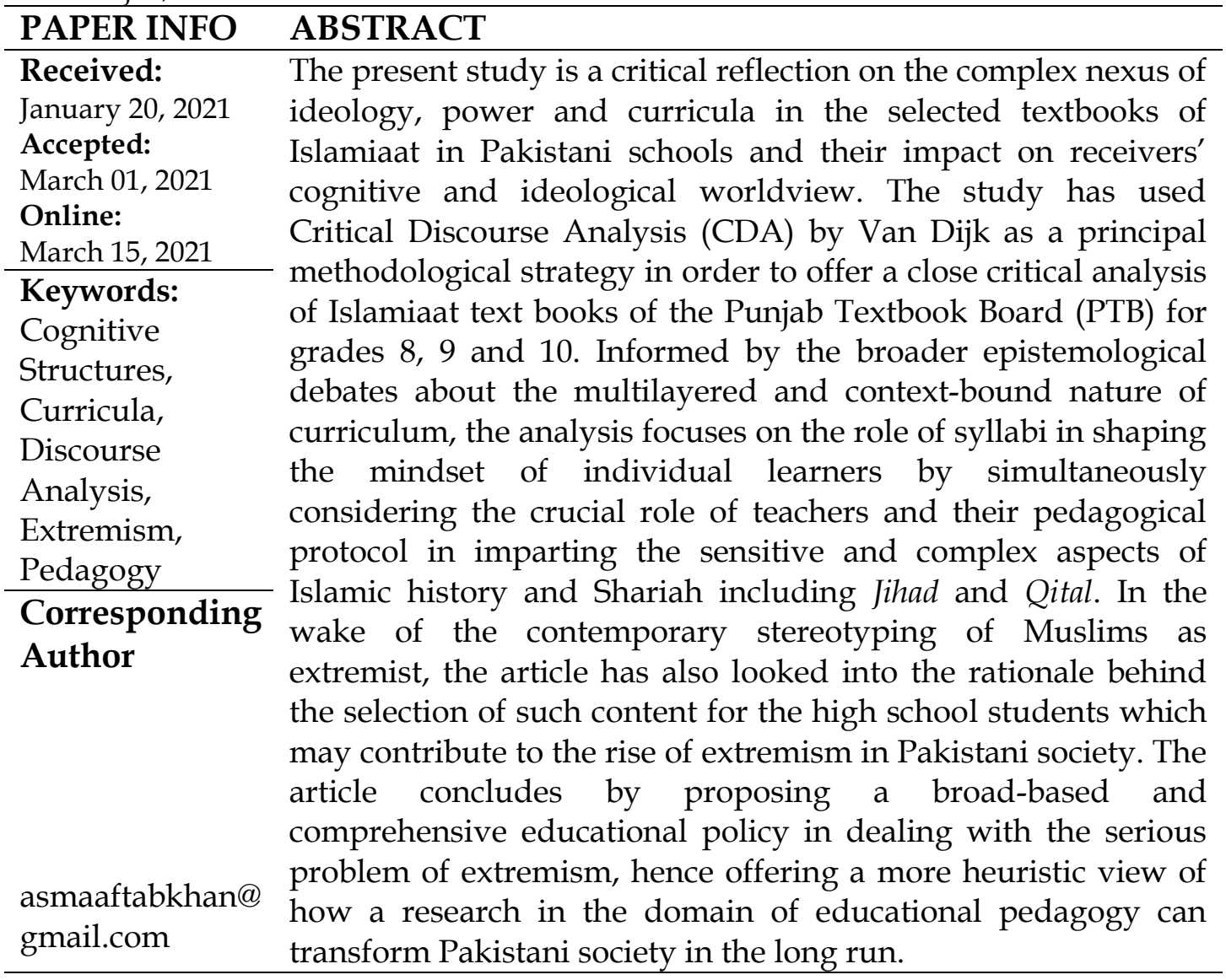

\section{Introduction}

There is no denying the fact that education sector, especially from primary to higher secondary school, has been one of the most crucial sites to develop a collective national belonging. However, even after many decades, the State of Pakistan has not been successful in offering a uniform and broad-based educational 
system for all students without dividing it into sharp cleavages of public and private institutions. As a result, educational policy in each government has continuously been juggled to suit the vested interests of the powerful and the ruling elite than to set its own priorities in order to achieve the real goals and ends of the nation state (Siddiqui, 2016). This inconsistency and confused educational landscape is further polarized in the presence of an advocate for an absolutely modern education system with its secular outlook and its counter view that vouches for a religious education policy with its more conservative interpretation.

Given that ideology plays crucial role in the design and development of curriculum, many educational scientists have argued that that this ideological indoctrination becomes problematic when it vies for the inclusion of what it regards as the 'Truth' by ignoring or absolutely excluding the other truths coming from the groups with lesser worth and power in the polity. In such scenario, the curriculum becomes the contesting ground with warring ideologies and the textbooks are converted into a potentially perilous medium promoting exclusion, intolerance and even radicalization among learners.

Without going into the debates between the religious and secular factions for their own justifying rhetoric to validate their stance, in the following lines, we have attempted to present a critical analysis of the selected content from Islamiaat textbook in order to highlight some cognitive implications of it for the learners and their impact on their subjective and collective outlook in the broader social context. Such analysis, far beyond a singular and narrowly focused linguistic analysis of the content, takes into consideration the intricate link between ideology, power and politics in contriving a particular discourse which in turn has constituted the fundamental worldview of students in the most formative period of their cognitive development as independent individuals as well as members of a polity. Our analysis also looks into the larger social and political ramifications of this content, which is likely to produce complicit and complacent subjects with a narrow vision of identity (either religious or national) without enabling them to develop critical thinking combined with social responsibility.

\section{Analytical and Methodological Trajectories}

As a qualitative research, the present study has attempted to explore the implicit ideologies in the selected content the Punjab Text Book Board (PTB) as one of the largest curriculum designers for Pakistan's public and private schools. As a matter of fact, text books are the primary medium of education in educational sector everywhere in the world, however, in Pakistan they are considered more significant and vital in the teaching schemes at every stage - from schools to universities. The reasons of this major reliance on textbooks can be numerous, however most importantly, since the teacher centralizes her teaching on the text books, they eventually become the pivot of pupil's world and serve as the epicenter of their cognitive development(Aziz, 2015, pp.211-228). Since ideology is subtly and deeply connected with textbooks, sometimes, they become hurdle in the way of critical thinking among students as they tend to develop and shape their minds towards 
certain thinking patterns by simultaneously limiting the role of teachers and specific family backgrounds and by treating them, more or less as homogenous groups.

\section{Van Dijk's Socio-Cognitive Model}

Out of the varied concerns of Critical Discourse Analysis (CDA), the present article has selected Dijk's socio-cognitive model to assess the ideological intervention of extremism in the selected content. Dijk believes that there is no direct relationship between social structures and discourse. Rather, they are connected to each other through personal and social cognition, which refers to personal and collective beliefs, goals, values, emotions, and other mental structures. Dijk's model of social cognition is categorized into two basic levels - Micro and Macro, however, in the present article, we have primarily used the key features of his macro analysis as they have informed our discussion about the selected content of Islamiaat Textbooks:

\begin{tabular}{cl}
\hline \multicolumn{1}{c}{ Macro Level of Cognitive Analysis } \\
\hline 1. & $\begin{array}{c}\text { Social Cognition } \\
\text { General } \\
\text { Particular }\end{array}$ \\
\hline $2 . \quad$ Memory \\
\hline $3 . \quad \begin{array}{l}\text { Generalization of Events and Norm Expression } \\
\text { Power Politics and Ideology }\end{array}$ \\
\hline $4 . \quad \begin{array}{l}\text { Self -Identity Description } \\
\text { Positive Self-representation and Negative Representation of Others } \\
\text { True and False Representation }\end{array}$ \\
\hline
\end{tabular}

The above-mentioned contents represent the basic framework of Dijk's sociocognitive model and the categories employed by him which have served as a befitting choice for analysis in the present research.

\section{Literature Review}

The renowned educationist Shahid Siddiqui, in his book, Education Policies in Pakistan argues that the "re-engineering of curricula" (p.203) in Pakistan is often orchestrated by those who have less understanding and exposure to the ground needs and problems facing Pakistani educational landscape. This conspicuous gap between State Policy and genuine educational needs of the people made it even harder to achieve the national goal of quality education with its shared objectives. Often the National Educational Policy in Pakistan is shaped and influenced by the political and ideological agenda of the ruling elite, hence fail to offer some holistic solutions to the complex educational needs of the country.

While the complex nexus between ideology and curriculum in the construction of subjective or collective identities has invited serious attention of educationist all over the world(Apple, Freire, Saigol, Rafiuddin), the problem has a 
particular relevance in case of Pakistan's educational domain. In view of Siddiqui, one can see the persistent presence of an "overarching ideology of Islam" (p.34) in almost all educational policies in Pakistan. Given that Islam has been the official religion of a majority of Pakistanis, there is nothing surprising in the inclusion of Islamic ideology in the curriculum as argued by Siddiqui. However, the problem surfaced when this particular view of religion or more precisely religious ideology started clashing and colliding with the fundamental principles of plurality, equal citizenship, social harmonyand coexistence which are crucial in the construction of a diverse polity with their multi-ethnic, multi-lingual and multi-religious beliefs.

Imtiaz Gull (2002) highlights the complex working of a particular religious ideology in the domain of education, especially in drafting the National Education Policy during Zia's regime. According to him, the textbooks were used to present and reinforce an ideal version of collective identity with a mix of religious and national ideologies in order to achieve legitimacy for Zia's rule, primarily his Islamization campaign. Paradoxically, this ideal version of Islamic state and citizenship was fashioned in the backdrop of some crucial political episodes in national history, most importantly the 1979 Afghan war and Pakistan's role in it as the frontline ally of America and Afghan Mujahideen. Consequently, the curriculum in following years was predominantly focused on Islamic concept of Jihad, particularly the armed struggle against non-Muslims etc. It is very pertinent to mention this historical and temporal context of the curriculum as it was shaped in the wake of Zia's Islamization at one hand and its subtle juxtaposition with Jihad in Afghanistan. Needless to say, Pakistan's open support for and participation in Afghan war considerably shaped the public perspective regarding the amorphous concepts of Jihad and Shahadat in Islamic faith. While this is not the subject to discuss the strategic dimension of Pakistan's support for Afghan war, our analysis in the following lines will focus on some serious ideological implications that this political event brought about for Pakistan's educational apparatus, particularly the educational ideology that informed and shaped the curriculum of Islamiaat in coming years.

\section{Analysis and Discussion}

The selected curriculum that we are going to analyze here has been thoroughly revised in the year 2006 with an inclusion of some selected chapters from Quran with their Arabic version with translation and interpretation in Urdu. The students in grade9 and 10 are expected to read, translate, understand and reproduce these selected verses in the class and are made to prepare them for their final examination. In this way, they are expected to read and understand a considerable portion of Quranic texts which, in many ways, become their first detailed introduction to the Divine book and its fundamental worldview.

\section{Textbook of Islamiaat in Grade 9}

Parallel to the scrutiny and analysis of the themes and contents of these text books, we have tried to analyze the implication as well as the ramifications of a 
specific discourse on the part of the students who usually receive them rather unreflexively. In this way, our argument attempts to challenge the specific readings or interpretations of Islamiaat textbooks, which, otherwise, can become potential sites of misinterpretations. The discourses selected from the selected textbook embody a glaring flaw in the selection of contents Islamic history, particularly from the life and times of the Prophet, his struggle to spread the message of Islam as well as other aspects of Muslim civilization developing and evolving in and after the life of the Prophet. Out of the major themes that this content imparts to the students, the Islamic concept of Jihad, especially the armed struggle against infidels by the Prophet and his Companions as well as their treatment with the enemies, mostly the hypocritical Muslims, requires particular mention. Our analysis in the following lines have attempted to look into the selection of these topics vis-à-vis their historical or logical pattern in the total context of Islam. In so doing, we will also probe what is the logic and rationale of this specific content in the textbook of Islamiaat and what is its impact on the cognitive outlook of the learners collectively?

Since the methodology of this analysis is primarily informed by the complex web of discourse and ideology in relation to power structures, our discussion of the selected content attempts to scan how the textbooks create certain discourses which are interconnected with war, warriors, jihad, and Qital in Islam and which, in turn, constitute the ideological outlook of the learners. Our analysis also uncovers the total effect of how this general perception about the Islamic faith, shape, directly or indirectly the cognitive structures of the readers/learners or vice the versa? Moreover, how does the collective outcome of this cognition manifest in the form of a contradictory and conflationary discourse about Islamic history and faith?

The first thing that a critical reading of the selected content highlights is that it is based on a flawed logic of teaching the students the later content - the MadniSurahsof Quran without giving them any idea about the prior content - the MakkiSurahs - and even before this, by ignoring the need to orient them with the overall context and vocabulary of the Quran. Since the lexical and semantic dimensions of the Quran, as an open-ended text, are complex and metaphorical, such ungraded and piecemeal reading and translation make students susceptible to draw mistaken conclusion about many aspects of their faith.

The first Surah that is included in the textbook in its original Arabic version along with the Urdu translation is Surah Anfal (8:12), which, according to its descending sequence, is one of the last series of the Quran revealed to the Prophet in Madina. It was the time when the holy Prophet was facing a rather difficult situation of countering the conspiracies of the hypocritical elements within Muslim community working in unison with the arch enemies of Islam - the Jews in the city and the infidels of Makkah. For this reason, the Surah is basically about war, warfare, strategy, the treatment of war prisoner, the war booty and other related instructions given to the Prophet in this difficult time. It is very pertinent to mention this immediate context of the Surah and the specific historical juncture when it was 
revealed to the messenger of Allah in order to understand the major themes and dominant tone of it. Undoubtedly, it is one of those sections of the Quran, where one can decipher the divine anger and wrath against the enemies of the Prophet. Therefore, at many times in the Surah, Allah has given absolute sanction to the Prophet to fight with sword against his adversaries, especially the hypocrites; use force against them to counter their conspiracies; not to accept any peace deal coming from them and exercise his right of revenge and retribution if needed. While there is no denying that such divine commandments were absolutely justified as the Prophet had been treating people with compassion and peace ever since his migration from Makkah to Madina, however, this Surah is singular and unique, as unlike many parts of the Quran, where divine benevolence and mercy is predominantly evident, it embodies an obvious tone of warning and intimidation from Allah against the enemies of Islam and the Prophet of Islam.

\section{A Skewed Representation of Jihad and Qital}

In line with Dijk's theorization about ideology and discourse, our analysis argues that the textbook of Islamiaat, especially in this section, offers a skewed representation of Jihad, especially when it comes to a direct armed struggle against infidels - termed as Qital in divine taxonomy. As mentioned before, the temporal context of Surah Anfal makes it specific as well as sensitive with a parallel, no less sensitive content as it extrapolates the furthest limits of Jihad.Since the immediate context and background of this Surahis the military confrontation between Muslims and theopponents, it is imperative that before reading such verses, the students should have a prior understanding of the specific conditions in which Islam has legitimized such a severe vengeance from the enemies and conspirators. Since the Muslims were not allowed to live with peace and freedom even after their migration to Madina, the Quran allowed them to resume jihad in order to resist and combat against aggression. Nonetheless, this gradual license that Islam has given to the Prophet for the use of force and that in such an intimidating tone, is rather a rare instance in the Quran. However, the inclusion of such verses in the textbook creates a discourse about the Islamic notion of Jihad by presenting it in isolation from the twin temporalities - the immediate time and context when a particular verse was revealed and the second temporality of its reception for the students/readers in current times. Consequently, majority, if not all learners, with no supplementary reading of other parts of Quran (especially those revealed in Makkah) are likely to consider the last option as first and in real life, this conflation could be highly misleading as it is likely to produce a radicalized and self-centered ideology as if it were sanctioned by Islam. In the absence of a gradual license for an open confrontation with the non-believers, the students' reading of this Surah is likely to become a potential misreading as if Muslim warriors were given absolute license of violence in the name of Jihad. Likewise, with no inkling of the stringent protocol of Jihad followed by Muslims during military confrontation, a sizeable number of students, despite believing in Islamic teachings of peace and harmony, are likely to be misled towards accepting some sort of justification to such radical and violenceprone ideology. 
A close scrutiny of this section offers a more problematic dimension of students' cognition where the complex notion of Jihad is flattened into an extreme notion of vengeance and violence and condition them to accept it by ultimately smudging the peaceful image of Islam. This becomes more conspicuous in the translation of the Surah where certain phrases are mentioned without their proper context and a necessary commentary before in order to clarify their crucial situatedness, hence may become potential site of misunderstanding regarding jihad.In the absence of such necessary explication, the text seems to offer a list of negative, even violent words and phrases which can be misinterpreted by the young readers, making them infer an altogether mistaken understanding of Islam's outlook towards non-believers. Some pertinent examples from this translated version are the expression like sar mar karurah do (p.9), unkiporpor mar kartorr do(p.9) ${ }^{1}$ which produce obvious conflation when they are read by the students either in fragments or out of context by excluding their temporal and thematic situatedness. Without going into the complex debates of translation, such version is an effect of justifying violence and abuse in the name of Jihad. Since the students are made to learn, repeat and memorize this content many times, it is likely to be ingrained in their cognition so as the shape their consciousness and conduct in specific modes which may become extremist, even violent in later years.

In his interesting analysis about the rise of extremism in the wake of Afghan war, the Pakistani American Social Scientist, Masood Ashraf Raja has argued that the very notion of Jihad sanctioned by Pakistan during Zia regime and later adopted by the Taliban rule in Afghanistan is an "extreme reading of the concept itself" by flattening its "semiotic and semantic" complexity, allowing " a Talibanistic imagination focus only on the most literalist and the most extreme interpretations of the concept" (p.27).As a corollary, despite that the real spirit of Islam advocates Muslims not to fight for material gains but for Allah's pleasure, this amorphous notion of divine pleasure is easily manipulated by the young minds so as to derive a mistaken notion of Jihad. It is very likely that an untrained, yet impressionable minds will assume this last option of the divine order as the first and will use this ideological indoctrination in justifying their acts of violence and aggression against their opponents. Consequently, the young minds are likely to develop a scanty and mistaken understanding of Jihad and a sizeable majority among them tends to conflate and confuse extremism with genuine spirit of faith and outright violence with Jihad.

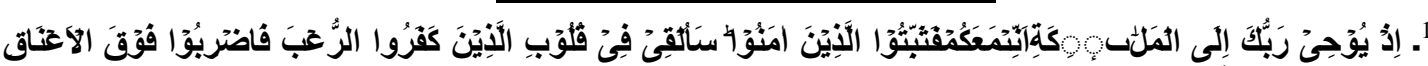

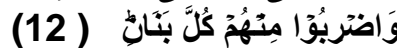

When thy Lord inspired the angels, (saying): I am with you, so make those who believe stand firm. I will throw fear into the hearts of those who disbelieve. Then smite the necks and smite of them each finger. 12

(Al-Quran Surah 8. Al-Anfaal, Ayah 12) 
Since there are no introductory lessons in earlier grades to help build sufficient pre-understanding, the students are exposed to such content which is going to impact their personal and social cognition in times ahead. The dilemma is more consistent with the fact that this out-of-context and fragmentary understanding of Islam is given to them without a comprehensive reading/perusal of the life of the Prophet and his companions, especially the hard times suffered by them in the early days of Islam in Makkah. In the same vein, they are not introduced with an ageappropriate and graded reading of the Quran and the life of the Prophet which can impart them a sense of universal human and social etiquette so as to shape their personal cognition and prepare them for some more complex lessons in next grades.

It is also pertinent to mention that parallel to this reductive view of Jihad, the students, in these verses, are exposed to the concept of God which is far more wrathful and vindictive than benevolent and merciful. This is evidenced from phrases like Khudachaalchalrahatha (p.13), azaab-e-aatishkamazachakhaoor halakkardaala(p.19) ${ }^{2}$ which describe Allah with his unbound anger and vengeance and likely to overshadow the otherwise merciful and compassionate image of God,so overwhelmingly present in the divine text.That to introducing students with this later version of their God is more vital in this formative stage of their moral and ideological development as it will eventually enable them to understand and appreciate the rationale behind divine visage of anger and wrath.In the absence of any parallel teaching of religious texts (at home and elsewhere), the curriculum becomes the sole source to shape the cognition of young learners who are easily swayed by a surface understanding and are likely to turn them into radicalized individuals insisting and superimposing their understanding on others. This particular discourse as contrived through curriculum with its blatant confusion in presenting the last option as the first one displays and transmits a narrow version of Jihad, hence, unwittingly, justifies the radicalclaims of a particular group with their misguided version of Islam.

\section{Islamiaat Textbook of Grade 8}

\section{Glorification of War and Warriors}

Besides the specific content from the Quran, the students in the subject of Islamiaat and Islamic history are exposed to war and war stories in order to orient them about the important episodes of Muslim history including the prominent military figures such as Tipu Sultan and MehmoodGhaznavi. These conquerors and warriors are presented as idealized characters embodying valor, devotion and military might which make them befitting subject in their struggle against their enemies, mostly non-Muslims.However, this representation of Islamic history with

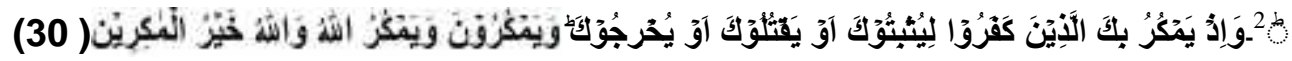

And when those who disbelieve plot against thee (O Muhammad) to wound thee fatally, or to kill thee or to drive thee forth; they plot, but Allah (also) plotteth; and Allah is the best of plotters. 30

(Al-Quran Surah 8. Al-Anfaal, Ayah 30) 
its martial figures is made in a manner which is one sided and singularly devoted to the glorification of war, military might and the idea of Muslim expansionism. Now the question is to see and ask what are the objectives of teaching students such episodes from history and what are the implication of such historical retrieval, especially when it is presented discursively to the young and impressionable minds? Moreover, what changes does this particular retrieval bring to a certain time or moment in Islamic history? What cognitive gains does this retrieval attempt to aim at and is likely to achieve?

In view of the above questions, we see that the Islamist textbook for class 8 contains a detailed story of the young warrior Muhammad Bin Qasim under the heading HidayatKaySarchashmay (Sources of Guidance) by narrating his life story including his childhood, education and his conquest of Sindh in the year 712. The opening line presents him as the youngest General in Islamic history with iron heart and resolve as he was sent to "askari school" for the training of Jihad at the age of five (p. 86). In referring to the Bin Qasim's engagement with Jihad throughout his life, the text seems to create an impression as if such heroism and valor are impossible to attain without a passion for war and expansion. In an attempt to highlight the significance of jihad in Islam and the lives of Muslims, the textbook makes a repeated display of such characters as the role models and the idea of war and military expeditions as the ultimate end of the Islamic political order.

However, seen from a purely cognitive angle, this one-sided representation is likely to result in strengthening a more power-hungry, even violent image of Islam with its political conquest and military adventure. Broadly speaking, a range of religious and political narratives with their singular focus on Islamic history in terms of its political goals, are interwoven in the textbooks of Islamiaat and History. However, ultimately such content has the effect of downplaying the ethical values of Islam as a Universal religion with its emphasis on humanity, magnanimity, compassion and justice. It is far more useful that prior to such discursive content about Jihad, military expansion and war, the students should have substantial understanding of the core human values which made the message of Islam more appealing and transformative for the poor, the weak and the underprivileged. At the same time, side by side with the representation of such martial figures with their military skills, the students should have a parallel understanding of the other, albeit no less important dimensions of Islamic civilization with its cultural, aesthetic and scientific progress. This will enable them to get a more holistic appreciation of Islam as a civilizational force which managed to influence people not merely on the bases of its military might and superiority, but as a transformational force impacting every aspect of their lives and shaping their outlook as ethical and moral beings.

One may assume that the textbook designers seem not to be conscious of the subtle cognitive implications of such content for the young minds. This becomes more conspicuous when we see that the students at this level are hardly acquainted with some parallel development in the fields of astrology, anatomy, medicine and 
physics with a host of illustrious figures working parallel to the political triumph and expansion of the Muslim Empire. In view of Aziz, such lopsided and scanty representation of Islamic history by the syllabus designers has brought about some serious cognitive implications for the students, making them potentially vulnerable to embracing a radical worldview in the later years of their lives.

On a similar note, in an important study regarding public perception about militancy and religious extremism, Sial and Anjum have argued how curriculum with its particular version of Jihad became the core reason behind many students' misperception with which they tend to conflate Jihad outright violence. Given the general incapacity of people for critical thinking combined with the failure or incapacity of the government and other educational institutions (media, schools and religious seminaries), it has become even harder to build a balanced narrative on these complex aspects which can control the radical discourses seeping into social structures. Needless to say, one can see the bitter fruits of this mistaken view of religious faith that Pakistani society has reaped (and is still reaping) in the backdrop of 9/11 with an increasing violence and lawlessness, which has made people further disillusioned about the real essence of Islam as a religion of peace and humanity.

\section{Conclusion}

The argument in above lines has highlighted how, in the absence of an alternative discourse on the subject of Islamiaat, Islamic History and Pakistan Studies, a sizeable majority of Pakistani educational institutions have incorporated such radical view as a popular discourse. A curriculum which tends to reinforce a binaristic view of the world hardly enables the learners to develop their critical thinking in order to acknowledge and appreciate the gray zones lying in between. Since the learners are often made to receive and respond to the textbooks uncritically and unquestionably, such conceptual haziness around many aspects of their faith and history continues to intrigue them. Given that there has been no revision or change over many years in the curriculum, it has virtually influenced many generations of students with such mistaken representation of Islam, especially the concept of Jihad.Despite that there have been some efforts by the State to introduce reforms in the curriculum, (one example of this is Musharraf's broad-based reform agenda for religious and secular institutions), however, far from bringing about a real change in the educational system, this reform agenda has remained largely ineffective, primarily because of a conspicuous gap between academic goals and their concomitant social and ideological context in our educational institutions.

Concluding the argument, we can say that curriculum in this way has become a potentially precarious site which might breed radical mindset.Thisbecomes more problematic as in dealing with these complex topics, the students are not encouraged to ask question and voice their confusion and are likely to develop a mistaken or partial understanding which continue to shape their minds and manners in later years. In this way, such content in the curriculum is likely to become potential site of endorsing religious extremism as the students are exposed to complex conceptual and ideological notions which are inserted into their syllabi 
without developing enough critical ability to understand and appreciate their specific context and place in the total worldview of Islam. 


\section{References}

Aftab, A. (2019). Discursive representation of the troubling position of Islam in Anglophone Pakistani fiction: A critical analysis. Pakistaniaat,7(19).

Aly, J. H. (2007). Pakistan national education policy: A white paper revised. National Educational Policy Review Team,Ideology and curriculum, New York: Routledge.

Aziz, K. K. (1993). The murder of history in Pakistan. Lahore: Sang-e-Meel.

Bašić, N., \& Siddiqui, A. H. (2009). Rethinking global terrorism. Islamabad: International Islamic University.

Bhatti, R. (2018, July 23). The politics of hate. The Nation.

Eagleton, T. (2014). Ideology. New York: Routledge.

Fairclough, N. (1993). Discourse and social change. Cambridge: Polity press.

Freire, P. (2007). Pedagogy of the oppressed. New York: Continuum.

Fayyaz, S. (2012). Pakistan response towards terrorism: a case study of Musharraf regime (Doctoral dissertation, University of Birmingham).

Gul, I. (2011). The Most dangerous place: Pakistan's lawless frontier. New York: Penguin books.

Khan, D. A. (2019, March 27). Roots of monolithic thinking amongst students in Pakistan: A critical analysis. Eqbal Ahmad Centre for Public Education.

Lukin, A. (2016, August 1). The study of ideology in a Post-Saussurean linguistics. prezi.com.

Punjab curriculum and text book board, Lahore [PTB]. (2019). Islamiaat (Compulsory) 9-10. Lahore: Shafeeq Ahmad Shakir Printers.

Punjab curriculum and text book board, Lahore [PTB]. (2017). Islamiaat 8. Lahore: Irfan press.

Rafiuddin, M. (1961). First principles of education. Karachi: Iqbal Academy Pakistan.

Raja, M. A. (2019). ISIS: Ideology, symbolics, and counter narratives. New York: Routledge.

Raja, M. A.(2011). Neoliberal dispositifand the rise of fundamentalism: The case of Pakistan. Journal of International and Global Studies, 3(1), 21-31.

Rashid, A. (2003). Jihad: The rise of militant Islam in Central Asia. Penguin Group. 
Saigol, R. (2019) Curriculum and constitution. Rethinking Pakistan, a 21 ${ }^{\text {st }}$ century perspective. Lahore: Folio Books.

Sial, S., \& Anjum, T.(2010). Jihad,extremism and radicalization: A public perspective.Conflict and Peace Studies, 3(2), 33-62.

UNESCO report says Pakistani textbook promote 'militarism and war'. (2017, December 6). Pakistan Today, p.1.

Van Dijk, T. A. (2006). Discourse and manipulation. Discourse and Society,17(3), 359383.

Van Dijk, T. A. (1977). Text and context. London: Longman. 